\title{
Kimble v. Marvel: A Misconceived Affirmation
}

\author{
Aditya Gupta*
}

\section{Abstract}

A clause in a patent license agreement which requires the licensee to continuously render royalty payments even after the intellectual property rights have expired has been a very controversial issue in practice. With the infamous United States Supreme Court Ruling of Brulotte $v$. Thys, and its subsequent affirmation in the case of Kimble v. Marvel, the legality of continued royalties seems to be a settled provision of law in the American Jurisprudence. However, the judgement rendered in the case of Kimble v. Marvel begs the question as to whether the affirmation was by reason of sound judicial interpretation or the coercion of stare decisis. The interplay between the rule of reason and the per se rule on one hand, with that of the patent misuse theory on the other, was alarmingly unclear. The three were presented as being so closely related that the two distinct dynamics of law could very well be addressed as excessive legislation on the same subject-matter. The present research seeks to analyze the 2015 ruling of Kimble $v$. Marvel, without the interference of stare decisis and defines the contours under which the judgement was rendered (patent law or antitrust). Most importantly, the paper will assess the Indian jurisprudential stand with reference to continued royalties, both within patent law and the competition law.

Keywords: Competition Act, 2002, Doctrine of Stare Decisis, Patent Misuse Theory, Per se Rule, Rule of Reason.

*National University of Study and Research in Law, Ranchi, India; aditya17497@gmail.com 


\section{Introduction}

A clause in a patent licensing agreement which requires the licensee to continuously render royalties has undeniably been a very controversial issue. Innumerable litigations concerning such payments have been brought forth for the scrutiny of the courts. Contentions ranging from deferring of risks to stifling innovation have time and again been cited in favor of continued royalties. ${ }^{1}$ Although, all such contentions and arguments have been in vain because of a per se prohibition on payment of royalties after expiration of the patent protection granted over the patent introduced in 1964 and affirmed in 2015.

The United States Supreme Court has always broadened the horizons of the Patent Misuse Doctrine ever since its inception in the case of Motion Pictures Patents. ${ }^{2}$ The doctrinal counter movement which was indulged into observed by the Circuit Courts and the District Courts after the Brulotte 3 judgment was finally put to rest, half a decade later in Kimble v. Marvel. ${ }^{4}$ The Supreme Court has reaffirmed the Brulotte ruling despite the opprobrium it had witnessed across the judicial and the academic spectrum. 5 The affirmation was again marred by academic criticism and was deemed to overlook the jurisprudential developments of the late $20^{\text {th }}$ Century and the early $21^{\text {st }}$ Century. The argued shift from the Patent misuse to Rule of Reason was sought to limit the scope of applicability of the former, to ensure better distribution of risk and a better economic environment.

The Ninth Circuit Court which dealt with the issue prior to the writ being filed before the Supreme Court, was also as reluctant to adhere to the Brulotte Rule. ${ }^{6}$ The dissenting opinion of the Kimble

${ }^{1}$ Barak Orbach, Antitrust stare decisis stare decisis stare decisis, 15 ARIZ. LEGAL STUdies PubliCATION, 1 (2015).

2 Motion Picture Patents Company v. Universal Film Manufacturing Company et al., 243 U.S. 502, 515 (1917).

${ }^{3}$ Brulotte V. Thys Co., 379 U.S. 29 (1964).

${ }^{4}$ Kimble v. Marvel Entertainment LLC, 135 U.S. 2401 (2015).

${ }^{5}$ Molly Mccartney, Caught In The Web Of stare decisis stare decisis stare decisis: Why The Supreme Court's Holding In Kimble V. Marvel Was Wrongly Decided, 16 WAKE FOREST J. OF BUS. \& INTELL. PROP..L., 492 (2016).

${ }^{6}$ Marvel Entertainment LLC v. Kimble, 727 F. 856 (2013). 
ruling and the critique of the majority ruling begs the question as to whether the affirmation was an effect of sound statutory interpretation or a judgment rendered under the coercion of stare decisis. The affirmation was also critiqued as being a transparent garb for clothing a decision rendered under the Anti-Trust laws as one rendered within the contours of the Patent Law. ${ }^{7}$ The reason for strict adherence to the Patent Misuse and the blatant disregard of the Rule of Reason has been the cornerstone of the critique witnessed by Kimble.

The present research directly elaborates the Brulotte rule and analyses the judgment of the Supreme Court in Kimble v. Marvel. ${ }^{8}$ The advantage that academic research enjoys is that unlike judicial interpretations it is not marred by policy concerns. Thus, the judgment of Kimble shall be analyzed without the interference of the doctrine of stare decisis. The historical underpinnings and the evolution of Patent Misuse along with its current understanding in the light of its relevance with the Rule of Reason, shall also form a segment of the present research. Most importantly, there is a dearth of literature explaining the legality of continued royalties within the Indian Jurisdiction. A section of the paper has been dedicated to address the Indian stance on post-expiration royalties.

\section{The Brulotte Rule}

The present research hinges on the reasoning employed by the majority while affirming the Brulotte rule. The Kimble Court in 2015 abjured an opportunity to bid adieu to the per se prohibition on post expiration royalties of patents-a move which was highly sought after by the American legal diaspora. The same can be evidenced by the nine amici curie filed in support of Kimble, as opposed to only five filed in support of Marvel. ${ }^{9}$ The Kimble case

${ }^{7}$ Maxwell C. Mcgraw, Kimble V. Marvel Entertainment, Llc: Economic Efficiency Caught In The Web Of Improper Judicial Restraint, 65 U. OF KAN. L. REV. 177 (2016).

${ }^{8}$ Kimble v. Marvel Entertainment LLC, 135 U.S. 2401 (2015).

${ }^{9}$ See also: Kelly Casey Mullally, Your Friendly Neighborhood Patent License: Should Royalty Payments Based on Postexpiration Use Be per se Unenforceable: Kimble v. Marvel Enterprises, Inc. (13-720), 42 Preview U.S. Sup. Ct. Cas. 238 (23). 
was being viewed as an opportunity to frustrate the Brulotte ruling, or at least revise it to meet the requirements of the $21^{\text {st }}$ Century. However, the decision upheld an arguably archaic and misconceived rule of law. ${ }^{10}$

In the present case, the Thys Company sold hop-picking machines. Each machine included several parts, which had individual protection under intellectual property law. The company extracted a licensing fee in lieu of the machines. The licensing agreements did not discuss the last date for payment of royalties and thus the royalty payments continued after the patent expiration. The purchasers subsequently discontinued the payment and a case of infringement was registered against them. With an 8:1 division of the Bench, Justice Harlan delivered the minority opinion while Justice Douglas delivered the majority opinion. The licensing agreement was commented as being a 'bald act of policymaking ${ }^{11}$ '. The majority judgment is responsible for a per se ban on postexpiration royalties on patent licensing agreements.

Although, the dictum rendered in the case of Brulotte was not a novel line of judicial reasoning, it was arguably brewed in the same barrel as some of its predecessors. Precedents supported the conclusion drawn by the Brulotte Majority. The first issue of post expiration royalties was adjudicated by the US Supreme Court in the case of Scott Paper Co. v. Marcalus Manufacturing Co. ${ }^{12}$, wherein it was held that "any attempted reservation or continuation in the patentee or those claiming under him of the patent monopoly, after the patent expires, whatever the legal device employed, runs counter to the policy and purpose of the patent laws." Subsequently, the Third Circuit Court followed a similar line of reasoning, where it was held that the patent monopoly was spent on the expiration of a patent and any attempt to exact royalties after the expiration of patent term was unenforceable. ${ }^{13}$ Thus, it can very well be submitted that

10 Jim Day \& Erik Olson, Three Significant Upcoming Patent Law Decisions Expected From The Supreme Court And Federal Circuit, Fabella Braun And Martel Llp., (Sep. 20, 2018) Https:// www.Bakerdonelson.Com/ Files/ March\%20ip\%20roundtable\%20outline.Pdf.

${ }^{11}$ Kimble v. Marvel Entertainment LLC, 135 U.S. 2401 (2015).

12 Scott Paper Co. v. Marcalus Manufacturing Co., 326 U.S. 249 (1945).

${ }^{13}$ Ar-Tik Systems Inc. v. Dairy Queen Inc., 302 F. 496, 510 (1962). 
Brulotte furthered the jurisprudence of the time and should not be arraigned as the harbinger of the per se prohibition of Post Expiration Royalties.

\section{Kimble v. Marvel}

In the interval of 40 years between the Brulotte rule being promulgated and the Kimble dispute being considered for adjudication by the Supreme Court, the per se prohibition had witnessed abundant criticism. With Justice Posner providing a very blunt and uninhibited criticism in Schieber v. Dolby Laboratories, Inc., ${ }^{14}$ along with Justice Berzon further strengthening the antiBrulotte reasoning in the 2007 case of Zila Inc v. Tinnell ${ }^{15}$ and the academic diaspora publishing various articles explaining the impracticality of the Brulotte rule ${ }^{16}$, the stage was set for an amendment to the prohibition with the Kimble dispute.

The Kimble litigation was concerned with the licensing agreement of a toy, over which a patent was obtained in 1991. Kimble had previously sued Marvel for patent infringement, with the litigation finally being concluded with a settlement agreement between the parties. Kimble 'royalty on net product sales' was obtained. Neither did the agreement stipulate any period for which the royalties were to be paid, nor did the agreement stipulate any reduction in the royalty rate after the expiration of the payment. Later Marvel 'stumbled across' the Brulotte rule and declared that they had no obligation to continue to render royalty payment, thus leading to the Court's getting involved.

The plaintiff argued for a departure from the per se prohibition, in favor of a case-to-case Rule of Reason approach. The court would have to take into account the anti or pro-competitive features of a licensing agreement and the economic effects which are most likely to register from the enforcement of the agreement. While substantiating the argument, Kimble argued that the Patent and Economic Policies favor a departure from the per se prohibition.

14 Schieber v. Dolby Laboratories Inc., 293 F. 1014 (2002).

${ }^{15}$ Zila Inc v. Tinnell, 502 F. 1014 (2007).

${ }^{16}$ Michael Koenig, Patent Royalties Extending Beyond Expiration: An Illogical Ban From Brulotte To Scheiber, 2 Duke L. \& Tech. Rev. 1 (2003). 
With a divided Bench (6:3), Justice Kagan delivered the judgment which affirmed the per se prohibition on post-expiration royalty arrangements, crippling the concerns which were time and again cited against the Brulotte rule. The majority opined that a licensing agreement which provides for payment of royalties after the expiration of the patent, incorrectly extends the rights accrued from the patent. The dissenting opinion was authored by Justice Alito who leaned on the majority's interpretation of stare decisis to question and negate the conclusions of the majority. The dissent was prominently based on the majority's interpretation of the Doctrine of Stare Decisis and statements like "State decisis does not require us to retain baseless and damaging precedent." 17 The Brulotte rule was criticized as the result of a singular antitrust concern, that post expiration royalties were an effort to enlarge the statutorily awarded monopoly. The relevance of the promulgation within the contours of the Patent Law was not examined and it was pointed out that nothing in the text of the Patent Act, 197018 "even arguably forbids licensing agreements that provide for post-expiration royalties."

The most controversial dictum of the judgment which also forms the basis of the present research, was that the dispute has been adjudicated entirely within the contours of the patent law and not the anti-trust law. While the latter provides for a wider scope of judicial interpretation and construction, the applicability of the former is statutorily dictated and there is minimal scope of judicial interpretation. Thus, any economic consideration cannot be submitted for adjudication because of the limited interpretative scope of the Patent Act, 1970.19

\section{Kimble without stare decisis}

Various authors have time and again remarked that the affirmation by the Kimble court was not a result of sound judicial interpretation,

\footnotetext{
${ }^{17}$ Kimble v. Marvel Entertainment LLC, 135 U.S. 2401 (2015).

18 The Patents Act, Act No. 39 of 1970, Acts of Parliament, 1994 (India).

19 The Patents Act, Act No. 39 of 1970, Acts of Parliament, 1994 (India).
} 
but a judgment rendered to respect stare decisis. ${ }^{20}$ The Court explicitly remarked "an argument that we got something wrongeven a good argument- cannot by itself justify scrapping a settled precedent. 21 "The Court quoted Justice Brandi," that it is more important the principle of law be settled than it be settled right." The fact that Brulotte was a case of statutory construction overlapping with the tenets of contract law, the force of stare decisis is at its acme. ${ }^{22}$

Despite an unequivocal confession that the principles underlying the Brulotte rule might be incorrect, the court declined to frustrate the settled principle of law. Academics have bluntly stated that, "Posner J.'s blunt criticism of the rule and the blatant reliance on stare decisis by the Kimble court shows that even the judiciary is covertly ashamed but too proud to concede." 23 The conclusion of the judgment also relied on the fact that Congress had held that the per se rule should not be relied on by the judiciary. The majority cited the case of Watson v. United States ${ }^{24}$ where the Court considered that no congressional interference for fourteen years accorded extra precedential importance to the judgement. The force of stare decisis and Congressional conduct made a very strong case against the overruling of the precedent.

The dissenting opinion in the case of Kimble v. Marvel25 also raises some genuine concerns about the application of stare decisis. The dissenting opinion delivered by Justice Alito, expressly states that stare decisis should not be perused to uphold a groundless and harmful precedent. Also, the fact that Congress has not indulged

20 A. Balto \& A.M. Wolman, Intellectual Property And Antitrust: General Principles.43 IDEA: J. OF L. \& TECH. 395 (2003); Herbert Hovenkamp, The Rule Of Reason, 70, FLORIDA L. REV., 96 (2018).

${ }^{21}$ Kimble v. Marvel Entertainment LLC, 135 U.S. 2401 (2015).

22 S.J. Waxman. May You Live In Interesting Times: Patent Law In The Supreme Court, 17 Chi. Kent J. Of Intell. Prop. 214 (2017).

23 Esther Valerie Mongare. Patent Term Under Review, Kimble V Marvel Entertainment Llc: Patent Term And Innovation, SSRN Electronic J., (2018).

24552 U.S. 74, 82-83, 128 S.Ct. 579, 169 L.Ed.2d472 (2007).

${ }^{25}$ Kimble v. Marvel Entertainment LLC, 135 U.S. 2401 (2015). 
into the analysis of the viability of a precedent should not be considered as a source of authority to a bad law. ${ }^{26}$

\section{Patent Misuse and Economic Concerns}

The Patent Misuse Doctrine is essentially a legal fiction i.e. a theoretical construction which does not find authority within a legislative framework. ${ }^{27}$ The doctrine is an equitable remedy which is analogous to the 'unclean hands' doctrine of Tort Law, which purports that any willful conduct that is iniquitous, unfair, dishonest, fraudulent, unconscionable, or performed in bad faith, can be a ground for the Court to deny any equitable relief claimed in the factual matrix. ${ }^{28}$ It denies the enforcement of a patent if the patentee abuses the privileges granted by the patent law. ${ }^{29}$

The 1917 case of Motion Picture Patents Co. ${ }^{30}$, has often been credited to have developed the affirmative defence of patent misuse. ${ }^{31}$ The patentee did not allow the purchasers to show moving pictures printed on competitors' film. The Court reiterated the principles underlying the registration of patents and laid down that the patent grant must be limited to the invention described in the claims of the patent. Subsequently, the doctrine was further substantiated in the case of Morton Salt v. Suppiger. 32 Suppiger required that licensees of its patented salt depositing machines use its unpatented salt tablets. The Brulotte case drew its importance from the fact that the Patent Misuse doctrine was freed from the shackles of tie-in arrangements and was implemented in the purview of Post expiration royalties. The Federal Courts of the late 20th Century

26 B. Orbach, Antitrust stare decisis stare decisis stare decisis 15 Arizona L. Discussion Paper 1 (2015).

27 Feldman, R.C., (2003). The Insufficiency of antitrust analysis for patent misuse. Hastings Law Journal, 55, p.399.

28 Ori J. Herstein, A Normative Theory Of The Clean Hands Defence, Cornell L. FAC. PUBL'N. PAPER 210 (2011).

29 Daryl Lim, Patent Misuse And Antitrust: Rebirth Or False Dawn, 20 Mich. TELECOMM. \& TECH. L. REV., 299 (2013).

${ }^{30}$ Motion Picture Patents Co. V. Universal Film Manufacturing Co., 243 U.S. 502 (1917).

${ }^{31}$ Cassandra Havens, Saving Patent Law From Competition Policy And Economic Theories: Kimble V. Marvel Entertainment, 31, Berkley TECH. L. J., 371 (2015).

32 Morton Salt v. Suppiger, 314 U.S. 488 (1942). 
attempted to limit the scope of the patent misuse doctrine. ${ }^{33}$ The case of Princov. ITC ${ }^{34} \mathrm{i}$ has been given special emphasis in this respect.

\subsection{Patent Misuse and Anti-Trust Analysis}

Patent Misuse as has been declared in the Kimble case, does not consider any economic or competitive repercussions of the alleged misuse. An anti-trust analysis, particularly the Rule of Reason, which was sought as a replacement to the per se prohibition by Kimble, rigorously examines whether an agreement unreasonably restricts competition. ${ }^{35}$ It means performing and analyzing any potential anti-competitive effects of a patent license and whether there are pro-competitive effects that outweigh the anti-competitive effects. ${ }^{36}$

The doctrine of Patent Misuse before the promulgation of Kimble v. Marvel was remarked as a 'Patent Anti-Trust Double Helix,' 37 , wherein an anti-trust analysis could have been indulged in to specify whether or not the concerned agreement is covered under the Patent Misuse Doctrine. In the year 2014, Prof. Daryl Lim published an article immediately before the Kimble case was up for adjudication before the United States Supreme Court and feared that the Supreme Court might disrupt the understanding of the Patent Misuse, which was developed by the Federal Circuit Courts. 38 The Supreme Court in the Kimble ruling explicitly declared that a Patent Misuse case could not indulge in an antitrust analysis.

33 Virginia Panel Corporation v. Mac Panel Corporation., 887 F. 880 (1995); B. Braun Medical Incorporated v. Abbott Laboratories, 124 F. (1997); Mallinckrodt Incorporated v. Medipart, 976 F. 700 (1992).

34 Princo Coporation v. International Trade Commission, 616 F.1318 (2010).

35 Daniel Fundakowski, The Rule Of Reason: From Balancing To Burden Shifting,

1 PERSPECTIVES IN ANTITRUST, 2 (2013).

${ }^{36}$ U.S. DEP'T OF JUSTICE \& FED. TRADE COMM'N, ANTITRUST ENFORCEMENT AND INTELLECTUAL PROPERTY Rights: PROMOTING INNOVATION AND COMPETITION (2007).

37 Daryl Lim, Patent Misuse And Antitrust: Rebirth Or False Dawn, 20 Mich. TELECOMM. \& TECH. L. REV., 299 (2013). ${ }^{38} \mathrm{Id}$. 
Other authors have also opined that a rule of reason approach is far superior than a per se prohibition on the provision of PostExpiration Royalties. The Kimble court has failed to appreciate that the issue in substance is patent leveraging and coercion, which is not necessarily a factor of extended royalty agreements. Wade and Warren argue that the modern anti-trust principles coupled with traditional judicial tools to confront fraud and coercion, are much better suited than per se or artificial rules that presume a harm or use of leverage that may not in fact be present. ${ }^{39}$ The argument fostered is one of merit, as not all patents ensure a leverage over an extremely competitive market, and what they accord is a possible market power.

Instead of providing a blanket prohibition, which stems from the reasoning that all patents entitle the patent holder to coerce the market into self-harming contractual relationships, the Courts should actually inquire into whether or not the questioned practice imposes an unreasonable restrain on competition. If the answer is in the affirmative, the Courts can very well declare the agreement void and restore what is espoused in Kimble, because following this approach won't allow several patents to realize their investments due to paucity of time.

\section{Analysis of Kimble v. Marvel}

Innumerable academic papers since the promulgation of the Kimble v. Marvel ruling in 2015 have strongly criticised the affirmation of the Brulotte rule. These criticisms can be broadly categorized into two--those which stem from the legal principles involved in the promulgation of the rule; and those which stem from equity and are not necessarily dependent on legal principles. For the sake of brevity, the former is labelled legal concerns and the latter is policy concerns.

\section{a. Legal Concerns}

The Kimble Court repeatedly argued that the Brulotter rule was based on statutory consideration of Patent Law and Contractual

39 Leslie Ware \& Jaden Warren, Rule Of Reason For Post-Expiration Patent Royalties, 11, J. Of INTELL. PROP. L. \& PRAC.,37 (2016). 
Law. Thus, emphasizing the effect of stare decisis on the judgment. Whereas, the fact of the matter is that apart from a passing reference made to the Article 8 of the American Constitution, no specific interpretation of singular provisions of the patent law was applied by the Brulotte Court.

The Brulotte court had opined that post expiration royalties increase the duration of the patent monopoly accorded to a patent by the sovereign authority. Such interpretation is erroneous subject to the fact that registration of a patent essentially embodies a right to exclude, which entitles the patent holder to exclude any person from infringing his patent. ${ }^{40}$ With the expiration of the patent, the right to exclude also expires ${ }^{41}$ and the technical know-how encapsulated by the registration is open to exploitation by the general public. The relationship between the licensor and licensee does not stem from patent laws, but from the contractual relationship they have previously established. The only case where the post-expiration royalties can extend the scope of a patent is when the patent enjoys tremendous market power and the licensor is able to coerce the licensee into an extended payment period for the patent. As has been previously elaborated, not all patents enjoy such market power and the Supreme Court's assumption is completely misplaced.

The per se ban on Post Expiration Royalties stifles competition, because it disincentivizes the registration of a patent, which is necessary to ensure that the patent comes into the public domain. The inventor, instead of registering his invention as a patent, can protect his invention as a Trade Secret. Such a move would result in the frustration of the quid pro quo principle of Patent Law.

The following two cases can further elaborate the scope of this hypothesis:

Warner Lambert Pharmaceutical Co. v. John J. Reynolds ${ }^{42}$, popularly known as the Listerine Case. The case involved the licensing of the formula which was required for the production of Listerine. A

${ }^{40}$ Hovenkamp, Supranote 14.

${ }^{41}$ Wolman, Supranote 22.

42 Warner Lambert Pharmaceutical Co. v. John J. Reynolds, 911 F. 970, 975 (1990). 
licensing agreement was entered into with Dr. Lawrence for the formula. By the time the case was instituted, a royalty amount of almost $\$ 2.2$ billion had already been paid with an accrued income of over $\$ 1.5$ billion due to be paid every year. The Listerine Formula had been completely in the public domain and had once even been published in the National Formulary and Journal of American Medical Association. Despite the formula being in the public domain, it was not attributable to negligence by the plaintiff or any of his predecessors in title. The question was whether after 75 years of paying royalty, the plaintiff was supposed to continue the rendering of royalties? The Court answered in the affirmative and declared that there is no bar on the payment of indefinite royalties and that the term of royalty payments shall be determined according to the terms of the licensing agreement. 43

Another such instance where post-expiration royalties in case of trade secrets was allowed is Aronson v. Quick Point Pencil Co. ${ }^{44}$ The case involved a pending patent application submitted on October 25,1956 . The underlying invention was licensed on the condition that if the patent application is successful and the patent is registered, the licensee would be subjected to a $5 \%$ royalty on the overall sales. However, in the event that the pending application is eventually unsuccessful and the patent is not registered, the royalty rate would be limited to $2.5 \%$. The application eventually failed and the subject 'invention' was not accorded patent protection. The license agreement was entered in June-July 1956 and the licensee sought a declaratory judgment to frustrate the agreement in October 1975. The Supreme Court considered the import of the Brulotte rule in the present case and opined that since during the negotiation of the licensing agreement no patent was involved, there was no threat of leveraging and coercion and the contract entered into between the parties was valid. ${ }^{55}$ What is interesting is that the Aronson decision has been considered by the Ninth Circuit

${ }^{43}$ Wie Lin Wang, A Study On The Legality Of Royalty Collection Clauses After Expiration Of Patent Rights, 15 THE JOHN MARSHALL REV. OF INTELL. PROP. L. 214 (2016).

${ }^{44}$ Aronson v. Quick Point Pencil Company, 440 U.S. 257 (1979).

${ }^{45}$ Frank Caprio, The Trouble With Brulotte: The Patent Royalty Term And Patent Monopoly Extension, 4 UTAH L. REV. 830-832 (1990). 
Court in the case of Kimble, wherein the lack of judicial coherence in the subject has been highlighted.

The above two decisions posit a very unique conclusion. Any invention which has been granted statutory patent protection cannot be the subject of an extended royalty agreement. Whereas, an 'invention' which is ineligible of patent protection or one in respect of which a patent application has not even been submitted, can very well be the subject of an extended royalty arrangement. These points towards an apprehension of the US Supreme Court, that whenever patent protection is involved, it is possible that the patent holder has coerced the licensee into an unfavorable licensing agreement. This apprehension has been so blinding that the court simply refuses to indulge in any analysis of whether or not such licensing agreements are actually coercive.

The jurisprudence behind the application of the Doctrine of Patent Misuse witnessed significant development ever since the Brulotte judgment. Although, thoroughly critiqued ${ }^{46}$, the Princo case has had a very important impact on the understanding of the Patent Misuse Doctrine. With the Princo ruling, patent misuse jurisprudence was substantially entangled with Anti-Trust concepts. The judgment unequivocally provided that misuse occurs when and only when the patentee abuses the protection granted with anti-competitive actions.

Kimble reaffirms the doctrine of cases holding that misuse is not anti-trust and does not need to be validated with actual anticompetitive effects. Without any deliberation over the Federal Circuit Courts' stride in the understanding of patent misuse, the Supreme Court overruled the Circuit Courts' 40 years' worth of efforts.

\section{b. Policy Concerns}

The Brulotte judgment itself provided for contracting clauses which could be incorporated to negotiate around the Brulotte prohibition. Kimble followed the same trend and enumerated the contracts

${ }^{46}$ Saami Zain, Misuse Of Misuse: Princo Corp. V. International Trade Commission and The Federal Circuit's Misguided Patent Misuse Jurisprudence, 13 N. C. J. OF L. \& TECH. 95 (2011). 
which are not prohibited by the ruling. It has often been suggested that these measures clearly indicate the court's acquiescence of the fact that the rule being promulgated by them comes with its fair share of economic headaches. ${ }^{47}$

The dissenting judgement of the Supreme Court has explicitly underlined that the alternate contracting arrangements are an economical inefficiency in themselves. The Majority expected the parties to draft and word their licensing agreement specifically keeping in mind the drafting plot embodied in the judgments. If such a trend of judicial intervention is allowed, the list of judgments which would require compliance would become very complicated. ${ }^{48}$ The dissent further highlighted that the alternate suggestions and contracting manoeuvres despite being a far more convoluted means to achieve the same end, fails to provide the same efficiency as an agreement providing for continued royalties. Such man oeuvres can potentially give rise to novel contracting terms and thus open a Pandora's Box of interpreting very intricately worded contract terms.

The most important policy concern relating to the per se prohibition stems from the fact that it can very well be perused as a tool to mislead the licensor into lower royalty rates. The factual scenario in Kimble v. Marvel is a classic example of this exercise. Marvel argued that they had 'stumbled across' Brulotte and subject to the rule enunciated therein, they were not willing to pay any royalties to Kimble henceforth. Parties which do not possess the legal acumen or the resources might be unaware of the Brulotte rule shall be at the losing end of the licensing agreement. ${ }^{49}$ On the other hand, parties which are well aware of the rule would ensure lower royalty payments extended over a longer period and subsequently

\footnotetext{
${ }^{47}$ Mcgraw, Supra note 8.

48 A similar view was posited in the Amicus Brief of Memorial Sloan-Kettering Cancer Center in conjunction with other research centres. Kimble v. Marvel Entm't, LLC, 135 S. Ct. 2401 (2015) (No. 13-720), 2015 WL 673668

49 Jason Rantanen, Exorcising The Spirit Of Justice Douglas, Patentlyo (Oct. 20, 2018), Https://Patentlyo.Com/Patent/2015/04/Exorcising-JusticeDouglas.Html; See also: S. Doyle, Brulotte Rule Upheld Despite Suspect Economic Rationale, (Oct. 20, 2018) http://www. americanbar.org/ content/dam/aba/publications/antitrust_law/ at303000_ ebulletin_ 20130122.authcheckdam.pdf.
} 
Aditya Gupta Interpreting Kimble v. Marvel in the light of Stare Decisis

can take refuge in the per se ban to frustrate the agreement. Thus, opportunistically taking unfair advantage at the cost of the other parties.

\section{Indian Perspective}

The history of patent misuse can be traced back to the Tek Chand Committee Report. ${ }^{50}$ The interim report was submitted on 4th August, 1949 with recommendations for prevention of misuse or abuse of patent right in India, and suggested amendments to Sections 22, 23 \& 23A of the Patents \& Designs Act, 191151along the lines of the United Kingdom Acts 191952 and 1949.53 Based on the recommendations of the Committee, a Bill was introduced in the Parliament in 1953.54 However, the Government did not press for the consideration of the bill and it was allowed to lapse.

With the advancement in the statute on the patent abuse hypothesis over the globe, the Indian government in the year 2008, presented a Department related Parliamentary Standing Committee Report on Patent and Trade System in India. The Department of Scientific and Industrial Research has pointed out the indispensability of a strong licensing system in the country, for ensuring business development.55 A resolution of the abovementioned legal conundrum is necessary for strengthening the licensing system.

\subsection{Lack of Judicial Instruction}

The Indian courts are yet to propound any judgment based on patent abuse precept unequivocally. Nonetheless, in the case of Telefonaktiebolaget LM Ericsson (PUBL) v. Competition Commission of

50 Parliamentary Standing Comm. ON COMmerce, ReP. ON PAT. \& TRADEMARKS SYS. IN INDIA (2018).

$51 \S 22,23 \&$ 23A, The Patent and Designs Act, No.2, Acts of Parliament, 1911 (India).

52 U.K. Patents Act, 1919, 9 \& 10 Geo. 5. c. 80.

53 U.K. Patents Act, 1949, 12 \& 13 Geo. 6. c. 62.

54 BILl No. 59, GAZETTE OF INDIA (1953),Http:// Egazette.Nic.In/ Writereaddata/1953/E-2254-1953-0049-104387.Pdf.

${ }^{55}$ Aronson v. Quick Point Pencil Company, 440 U.S. 257 (1979). 
India, 56 the issue of abuse of patent rights resulting in anticompetitive consequences was raised, which in a nutshell is the essence of patent misuse. The defendant companies, Micromax and Intex, had accused the plaintiff company, Ericsson, of abusing its position of dominance. Ericsson had entered into separate licensing agreements with Micromax and Intex with respect to Standard Essential Patents. It was alleged that Ericsson was extorting unfair royalty rates and limiting the development of technology in the relevant field, by seeking such high royalties. They were able to do so because the Indian manufacturers were being denied market access. The Competition Commission of India in its order held that the practices adopted by Ericsson were against the principle of FRAND (fairness, reasonableness and non-discrimination). The Court held that pressurizing the implementer to accept nonFRAND terms amounted to abuse of a dominant position.

The ground for allegations against Ericsson was Section 4 of the Competition Act, 2002,57 which prohibits abuse of dominant position by any enterprise. Demanding excessive royalties was read as denial of market access, which constituted abuse of dominant position. The question of whether seeking royalties beyond the expiration of the patent protection also constitutes abuse of dominant position has not yet been raised.

As has already been observed in the present paper, there is an acute paucity of literature on the issue of post-patent royalties in India except for a 2009 Delhi High Court judgment 58 , which simply holds that patent-holder cannot demand post-patent royalties, without actually proffering any rationale for the same. The Court clearly observed that:

Where the statute provides that the patent is allowed only for a limited period, the license of the patent cannot extend beyond that limited period. A license agreement for patents can be valid only during the

56 TelefonaktiebolagetLm Ericsson (Publ) v. Competition Commission Of India, (2016) 1 DLT 232 (India).

57 §4,The Competition Act, No.12, Acts of Parliament, 2003 (India).

58 National Research Development Corporation v. Abs Plastics Ltd,(2009) 40 PTC 613 (India). 
currency of the patent. Where the patent itself expires, the license of the patent also expires.

Dr. Vahini, an assistant professor at the National Law School of India University, Bangalore observed that within the Indian Legal Spectrum an agreement requiring royalties to be paid even after the patent has expired, constitutes as being a practice which hampers competition. ${ }^{59}$ Keeping in view the above perceptions made, it can be seen that the Indian judicial system is a long way behind and it is imperative that the judiciary take into consideration the aforementioned misbehaviours and attempt to counter them. The decisions must be sound, uniform and leave minimal room for loopholes to be found, otherwise the plethora of judgments will serve no purpose whatsoever.

In the light of the dearth of academic literature and judicial instruction, this part of the paper argues that Section 3 of the Competition Act, 200260 which specifically prohibits anticompetitive agreements does not institute a per se prohibition on agreements, which purport payment of continued royalties. Similarly, Section 140 and Section 141 of the Patent Act, 197061 restrain the imposition of certain restrictive covenants in Patent related agreements. Neither of these sections provide for any exclusion of covenants related to post-expiration royalties.

\subsection{The Competition Act, 2002}

Section 3 read with Section 19, sub-section 3 of the Competition Act, $2002^{62}$ determines the scope of covenants which have an Appreciable Adverse Effect on Competition (AAEC) within a market. An agreement providing for continued royalties alleged as being anti-competitive, would be judged on the pedestal of Section 3.63Section 3, sub-section5 ${ }^{64}$ carves an exception for anti-

\footnotetext{
59 VERSHA VAHINI, INDIAN COMPETITION LAW $1371^{\text {st }}$ Ed. (2015).

60 §3,The Competition Act, No.12, Acts of Parliament, 2003 (India).

$61 \S 140,141$ The Patent and Designs Act, No.2, Acts of Parliament, 1911 (India).

62 TelefonaktiebolagetLm Ericsson (Publ) v. Competition Commission Of India, (2016) 1 DLt 232 (India); §19(3), No.12, Acts of Parliament, 2003 (India).

63 TelefonaktiebolagetLm Ericsson (Publ) v. Competition Commission Of India, (2016) 1 DLT 232 (India).
} 
competitive agreements which are in reasonable juxtaposition with the bundle of rights granted by virtue of Patent Act, 1970.65Therefore, it would be safe to say that there is no explicit prohibition against extended royalty agreements and a Rule of Reason approach will be employed to address any allegation against such covenants. ${ }^{66}$

A detailed analysis of Section 3 is made herein under: Section 3, sub-section $1^{67}$ lays down the general prohibition against use of anti-competitive agreements, while Section 3, sub-section $2^{68}$ declares that any agreement to such effect shall be void. Section 3, sub-section $3^{69}$ identifies four types of horizontal agreements and puts such agreements on a unique pedestal, owing to the possible pernicious effect that these agreements can potentially have on the free market. Although, the standard associated with these agreements is also not the same as the per se Rule. ${ }^{70} \mathrm{In}$ fact, Section 3 , sub-section $3^{71}$ uses the words shall presume which institutes a refutable presumption in favour of AAEC. The burden of proof rests on the Defendant to show that the agreement does not cause any AAEC in accordance with Section 19, sub-section3.72 A similar view has been expressed in the case of FICCI Multiplex Association of India v. United Producers/ Distributors Forum (UPRF), 73 where the commission held that the presumption contained in S. 3(3) is rebuttable and the parties may present evidence to controvert the

64 §3(5), The Competition Act, No.12, Acts of Parliament, 2003 (India).

65 S. Chakravarthy, Competition Act, 2002: The Approach, In, TOWARDS A FUNCTIONAL COMPETITION POLICY FOR INDIA.

66 ParamjeetBerawal, Section 3(5)(I) Of The Competition Act- An Analysis, 27 NLSIR 168 (2015).

67 §3(1), The Competition Act, No.12, Acts of Parliament, 2003 (India).

68 §3(2), The Competition Act, No.12, Acts of Parliament, 2003 (India).

69 §3(3), The Competition Act, No.12, Acts of Parliament, 2003 (India).

70 ARIJIT Pasayat, SudHANSHu Kumar, S.M. Dugar's Guide OF COMPETITION LAW, 208, $2096^{\text {th }}$ Ed. (2016).

${ }^{71}$ Berawal, Supranote 72.

72 Uniglobe Mod Travels Pvt. Ltd. v. Travel Agents Federation Of India, (2011) COMPLR 400; M/S Snatuka Associates Pvt. Ltd. v.. All India Organisation Of Chemists And Druggists, (2013) COMPLR 223.

73 Federation Of Indian Chambers Of Commerce \& Industry Multiplex Association Of India v. United Producers/ Distributors Forum, (2011) CompLR 79. 
presumption contained therein.Section3, sub-section $4^{74}$ identifies a number of vertical agreements which are subject to the 'rule of reason' test. That would determine whether or not the concerned agreement has an AAEC in the domestic Indian Market. ${ }^{75}$ The conclusion of such assessment would determine whether or not an agreement is anti-competitive.

In conclusion, not only does the Competition Act, 2002 acknowledge the unique nature of intellectual property rights, but also does not provide for a per se prohibition within its statutory scheme. Therefore, the judiciary cannot find recourse under this law to institute a prohibition of post-expiration royalties in India.

Sections 140 and 141 of the Patent Act, 197076provide for certain conditions which aren't enforced because of their restrictive nature, while covenants like Exclusive Grant Back and Coercive package Licensing have found relevance in the statutory scheme. Suffice it to say that the scheme of the legislation does not in any way preclude post expiration or continued royalties.

\section{Conclusion}

The majority in Kimble relied on the Doctrine of stare decisis to uphold the Brulotte rule. ${ }^{77}$ The purpose of the doctrine is to ensure stability in commercial agreements and to allow the public to enter into legally binding covenants, with absolute certainty. The tradeoff between stability and reasonability is one of essence here. Trading reasonability for stability should not be indulged into by the Courts. Reasonable laws are far more important than stable laws, as was highlighted by the minority in Kimble. While acknowledging that Brulotte may stifle innovations or obstruct competition in some circumstances, the Court doled out the responsibility of drafting a relevant prohibition to the Congress. This violates the sanctity of the three pillars understanding of a democratic setup and the idea of Separation of Powers.

\footnotetext{
${ }^{74}$ §3(4)The Competition Act, No.12, Acts of Parliament, 2003 (India).

75 Subhadip Ghosh \& Thomas W. Ross, The Competition (Amendment) Bill 2007:

A Review And Critique, ECON. \& POl. WKLy., Dec. 20, 2008, At 35.

$76 \S 4$,The Competition Act, No.12, Acts of Parliament, 2003 (India).

77 Kimble v. Marvel Entertainment LLC, 135 U.S. 2401 (2015).
} 
As far as the Indian jurisdiction is concerned, it is an accepted fact that the Intellectual Property jurisprudence of Indian Courts lags far behind that of its Western counterparts. The lack of any judicial instruction on the present subject is a prime example of this 'catching-up' regime. The scarce judicial opinion which is available, is ill-reasoned at best. This analysis submits that the relevant provisions available in the Competition Act, 2002 and the Patents Act, 1970 do not warrant a prohibition of continued royalties without a case-based analysis of the subject. The lack of reasoning and statutory interpretation in the National Research Corp 78 case renders the judgment Per Incuriam and therefore denudes it of all precedential authority.

Robust policy guidelines would be able to act as an efficient solution to the problem of post patent protection expiration royalties. What must be remembered is that the collection of royalties has several advantages and disadvantages. The policy must attempt to strike a balance between both. Section 19 of the Competition Act, $2002^{79}$ should further be developed by way of administrative rules and regulations to aid judicial conclusion. This would ensure that there would be a balance of interests in the judgments' passed in this regard.

78 BILl No. 59, GAZETTE OF INDIA (1953), http:// egazette.nic.in/ writereaddata/1953/e-2254-1953-0049-104387.pdf.

79 §19 The Competition Act, No.12, Acts of Parliament, 2003 (India). 